\title{
EFFECT OF PLANTING METHODS AND NITROGEN FERTILIZER RATES ON THE PRODUCTIVITY OF RICE (Oryza sativa L.)
}

\author{
Sorour, F. A* A. Y. Ragab* T. F. Metwally ${ }^{\star \star}$ A. A. Shafik ${ }^{\star \star \star}$ \\ *Agronomy, Dept. faculty of Agriculture, Kafrelsheikh University, \\ Egypt. ${ }^{* *}$ Rice Research and Training Center, Agriculture \\ Research Center. ${ }^{* \star *}$ Edffina Farm, Production Sector, \\ Agricultural Researches Center, Egypt
}

\begin{abstract}
The present study was carried out in the two seasons of 2014 and 2015 at the Edffina Experimental Farm of Production Sector, Agricultural Research Center, Edco, El-Beheira Governorate, Egypt. The main objective of this study was to identify the effect of nitrogen rates $(0,50,100$ and $150 \mathrm{~kg}$ $\mathrm{N} \mathrm{ha}^{-1}$ ). on growth and production of Giza 179 and Sakha 104 rice cultivars under two sowing methods (Transplanting and broadcasting). Two experiments were laid out in split plot design based on RCBD in four replications in each sowing methods. Main plots were assigned to rice cultivars and the sub-plots to nitrogen rates. A combined analysis was used between sowing methods in each season. The results obtained show that application of transplanting method significantly increased number of panicle $\mathrm{m}^{-2}$, number of filled grains per panicle ${ }^{-1}$, number of unfilled spikelets panicle ${ }^{-1}$, 1000 -grain weight, grain yield and straw yield compared with broadcasting method in both seasons. The cultivar Giza 179 surpassed Sakha 104 number of panicle $\mathrm{m}^{-2}$, number of filled grains per panicle ${ }^{-1}$ and grain yield. While the later recorded the higher values of 1000-grain weight, number of unfilled spikelets panicle ${ }^{-1}$ and straw yield in the two seasons. Increasing nitrogen rate up to $150 \mathrm{~kg} \mathrm{~N}$ ha-1 significantly increased number of panicle $\mathrm{m}^{-2}$, number of filled grains per panicle ${ }^{-1}$, number of unfilled spikelets panicle ${ }^{-1}$, grain yield and straw yield. Except 1000-grain weight, all the mentioned traites were gradually decreased by each increased of nitrogen fertilizer in both seasons. The inverse was true in 1000-grain weight. The highest grain yield was obtained from adding 150 or $100 \mathrm{~kg} \mathrm{~N}^{-1}$ to the rice cultivar Giza 179 sown by transplanting method in the two seasons. It can be concluded that transplanting of Giza 179 received $100 \mathrm{~kg} \mathrm{~N} \mathrm{ha}^{-1}$ could be recommended for optimum grain yield under these conditions.
\end{abstract}

Key words: rice, planting methods, nitrogen fertilizer, cultivars

\section{INTRODUCTION}

Rice (Oryza sativa L.) is one of the most important food crops, in the world's providing a staple food for nearly half of the global population (FAO 2004; Anonymous 2009). In Egypt, rice is considered as the second important cereal crop after wheat as main food for 
Egyptian population Badawi (1999). Rice is grown mostly in the northern part of the Nile Delta. Most of these areas are classified as saline soils. Grain yield is considered the main objective in the rice breeding program. It is dependent on component traits and economic return. The decrease of grain yield and its components under saline soil for different genotypes were reported in many investigations.

Nitrogen fertilizer is one of the most important agronomic inputs and limiting factors realizing the potential rice grain production in the world. Use of adequate nitrogen rate is important not only for obtaining maximum economic return, but also to reduce environmental pollution Excessive nitrogen application can result in accumulation of large amounts of post harvest residual soil $\mathrm{N}$. Residual soil $\mathrm{N}$ may be available for subsequent crops in the next seasons, but such $\mathrm{N}$ is highly susceptible to leaching during non-crop periods ( Fageria and Baligar 2003). Nitrogen ( $N$ ) is considered to be one of the most essential nutrition elements for rice growth in natural ecosystems.

Subsequent field research revealed that improved nitrogen fertilizer use efficiency to achieve both high yields and high grain quality requires careful attention to the rate and timing of nitrogen fertilizer application such that the total available nitrogen supply from soil and fertilizer is congruent with crop nitrogen demand. In high-yield production systems, improved congruence between nitrogen supply and crop demand sometimes requires several split applications including final nitrogen topdressing at flowering stage. (Metwally et al., 2011).

The main objectives of the present study was to obtained the effect of different nitrogen rates application under saline soil condition on growth and production of Giza 179 (Indica Japonica type) and Sakha 104 (Japonica type) rice cultivars, under transplanting and broadcast seeded rice planting methods.

\section{MATERIALS AND METHODS}

This experiment was conducted during 2014 and 2015 rice growing seasons at the Edffina Experimental Farm of Production Sector, Agricultural Research Center, Edco, El-Beheira Governorate, Egypt to study the effect of cultivation methods and different nitrogen rates application on growth and production of tow Egyptian rice cultivars Giza 179 and Sakha 104. The previous crop was faba bean in the two seasons. Some soil chemical and physical properties of the experimental sites are presented in Table (1). 
Table (1): Some physical and chemical properties of the experimental soil before planting in 2014 and 2015 summer seasons

\begin{tabular}{|c|c|c|}
\hline Soil nronerties & 2014 & 2015 \\
\hline \multicolumn{3}{|l|}{ Particle size distribution } \\
\hline \multirow{3}{*}{$\begin{array}{l}\text { Clay \% } \\
\text { Silt \% } \\
\text { Sand \% } \\
\text { Texture (Clayey) }\end{array}$} & 55.90 & 56.00 \\
\hline & 31.50 & 32.00 \\
\hline & 12.60 & 12.00 \\
\hline \multirow{6}{*}{$\begin{array}{l}\text { Chemical: } \\
\text { Organic Matter (O.M)\% } \\
\text { pH(1:2.5 soil suspension) } \\
\left.\text { Ec (ds.m }{ }^{-1}\right) \\
\text { Total N (ppm) } \\
\text { Available P (ppm) } \\
\text { Available K (ppm) }\end{array}$} & 1.45 & 1.50 \\
\hline & 8.10 & 8.34 \\
\hline & 3.25 & 3.12 \\
\hline & 308.00 & 310.00 \\
\hline & 2.32 & 2.25 \\
\hline & .386 .90 & .364 .50 \\
\hline \multirow{4}{*}{$\begin{array}{l}\text { Soluble anions, meq. } \mathrm{L}^{-1} \text { : } \\
\mathrm{CO}^{-} \\
\mathrm{HCO}_{3}^{-} \\
\mathrm{Cl}^{-} \\
\mathrm{SO}^{--}\end{array}$} & 0.80 & 0.75 \\
\hline & 5.40 & 5.35 \\
\hline & 4.20 & 4.60 \\
\hline & 1.30 & 1.45 \\
\hline \multirow{4}{*}{$\begin{array}{l}\text { Soluble } \text { Cations, meq. } \mathrm{L}^{-1} \\
\mathrm{Ca}^{++} \\
\mathrm{Mg}^{++} \\
\mathrm{Na}^{++} \\
\mathrm{K}^{+}\end{array}$} & 1.40 & 1.50 \\
\hline & 1.70 & 1.80 \\
\hline & 8.30 & 8.40 \\
\hline & 0.30 & 0.45 \\
\hline
\end{tabular}

Two field experiments (one for transplanting and another one for broadcasting) were laid out in split design plot in four replications, where main plots were assigned to rice cultivars. While, the sub-plots were allocated to nitrogen rates $\left(0,50,100\right.$ and $\left.150 \mathrm{~kg} \mathrm{~N}^{-1}\right)$. A combined analysis was used between the two experiments in each season. Bartlett's test was used to assess homogeneity of error variance prior to combine analysis over environments. Nitrogen was applied in the form of urea $(46.5 \% \mathrm{~N})$. In the transplanting experiments, $\mathrm{N}$ was applied in two splits, i.o. $2 / 3$ as basal and incorporated into the soil immediately before flooding, followed by the second dose after 30 days from transplanting. In broadcast seeded experiment, $\mathrm{N}$ was applied in three equal splits, first dose as a basal application just before flooding, followed by the second and the third with 30 days intervals. Pre-germinated seeds were uniformly broadcasted in the nursery and in the broadcast seeded field on $10^{\text {th }}$ and $15^{\text {th }}$ May of the two seasons, respectively. All agronomic practices were followed as recommended during the growing seasons.

\section{Number of panicles $\mathrm{m}^{-2}$}

\section{RESULTS AND DISCUSSION}

Number of panicles $\mathrm{m}^{-2}$ was significantly affected by methods of planting (Table 2). The greatest number of panicles $\mathrm{m}^{-2}$ was obtained by transplanting rice. This was mainly due to maximum 
number of tillers at different growth stages in regular transplanting compared with broadcasting. Same result was obtained by Ali et al. (2013). Giza 179 rice cultivar recorded more number of panicles $\mathrm{m}^{-2}$ than Sakha 104. Increasing nitrogen rate up to $150 \mathrm{~kg} \mathrm{~N}^{-1}$ significantly increased number of panicles $\mathrm{m}^{-2}$. Increases in number of panicles $\mathrm{m}^{-2}$ due to nitrogen application could be attributed mainly to the role of nitrogen in the stimulation of cell division resulting in more tillers formation, also might be due to the more availability of nitrogen that played a vital role in panicle formation during the productive stage of the rice plant. The promoting effects of nitrogen on number of panicles $\mathrm{m}^{-2}$ were reported by Abd El-Hamed (2002).

Table 2: Panicle numbers $\mathrm{m}^{-2}$, length and weight of rice cultivars as influenced by method of planting and nitrogen rates

\begin{tabular}{|c|c|c|c|c|c|c|}
\hline \multirow[t]{2}{*}{ Factor } & \multicolumn{2}{|c|}{ No. of panicles $\mathrm{m}^{-2}$} & \multicolumn{2}{|c|}{$\begin{array}{l}\text { No. of filled grains } \\
\text { panicle }\end{array}$} & \multicolumn{2}{|c|}{$\begin{array}{l}\text { No. of unfilled } \\
\text { spikelets panicle }^{-1}\end{array}$} \\
\hline & 2014 & 2015 & 2014 & 2015 & 2014 & 2015 \\
\hline $\begin{array}{c}\text { Methods M: } \\
\text { Broadcasting } \\
\text { Transplanting } \\
\text { F-test }\end{array}$ & $\begin{array}{c}433.25 \\
591.00 \\
\star \star\end{array}$ & $\begin{array}{c}434.10 \\
594.99 \\
\star \star\end{array}$ & $\begin{array}{c}93.53 \\
114.76 \\
\star \star\end{array}$ & $\begin{array}{c}92.05 \\
112.72 \\
\star \star \\
*\end{array}$ & $\begin{array}{c}8.91 \\
11.98 \\
\star \star\end{array}$ & $\begin{array}{c}8.72 \\
11.82 \\
* *\end{array}$ \\
\hline $\begin{array}{c}\text { Cultivars C: } \\
\text { Giza 179 } \\
\text { Sakha } 104 \\
\text { F-test }\end{array}$ & $\begin{array}{c}530.56 \\
493.81 \\
\star \star\end{array}$ & $\begin{array}{c}532.90 \\
496.18 \\
\star \star\end{array}$ & $\begin{array}{c}108.38 \\
99.92 \\
\star \star\end{array}$ & $\begin{array}{c}106.90 \\
97.92 \\
\star *\end{array}$ & $\begin{array}{c}9.47 \\
11.42 \\
* *\end{array}$ & $\begin{array}{c}9.29 \\
11.24 \\
* *\end{array}$ \\
\hline $\begin{array}{c}\mathrm{Kg} \mathrm{N} \mathrm{ha}^{-1} \mathbf{N}: \\
0 \\
50 \\
100 \\
150 \\
\text { F-test }\end{array}$ & $\begin{array}{c}467.56 d \\
495.56 c \\
528.75 b \\
556.87 a \\
\star \star\end{array}$ & $\begin{array}{c}469.87 d \\
495.93 c \\
529.18 b \\
563.18 a \\
\star \star\end{array}$ & $\begin{array}{c}82.66 d \\
98.61 c \\
111.06 b \\
124.26 a \\
\star \star\end{array}$ & $\begin{array}{c}81.07 d \\
97.03 c \\
109.15 b \\
122.38 a \\
\star *\end{array}$ & $\begin{array}{c}6.05 d \\
9.06 c \\
11.91 b \\
14.76 a \\
\star *\end{array}$ & $\begin{array}{c}5.83 d \\
8.83 c \\
11.79 b \\
14.60 a \\
* *\end{array}$ \\
\hline $\begin{array}{c}\text { Interaction } \\
\text { M X C } \\
M \times N \\
\text { C X N } \\
\text { M X C X N }\end{array}$ & $\begin{array}{l}\text { * } \\
* * \\
* * \\
* \text { * }\end{array}$ & $\begin{array}{l}\text { N S } \\
\star * \\
* * \\
\star *\end{array}$ & $\begin{array}{l}\text { N S } \\
\star * \\
* * \\
* *\end{array}$ & $\begin{array}{l}\text { N S } \\
\star * \\
* * \\
* *\end{array}$ & $\begin{array}{l}\text { NS } \\
\text { NS } \\
* \\
\text { NS }\end{array}$ & $\begin{array}{l}\text { NS } \\
\text { NS } \\
\text { NS } \\
\text { NS }\end{array}$ \\
\hline
\end{tabular}

${ }^{*},{ }^{* *}$ and NS indicate $\mathrm{p}<0.05, \mathrm{p}<0.01$ and not significant, respectively. Means of each factor designated by the same letter are not significantly different at $5 \%$ rate using Duncan's multiple range test.

The interaction effect among planting methods, rice cultivars and nitrogen fertilizer rates in both seasons on the number of panicles $\mathrm{m}^{-2}$ are presented in Table 3. Data show that there was a significant effect in number of panicles $\mathrm{m}^{-2}$ due to the three-way interaction. Application of $150 \mathrm{~kg} \mathrm{~N}^{-1}$ to transplanted Giza 179 cultivar recorded the highest number of panicles $\mathrm{m}^{-2}$. On the other hand; the lowest values were found when Sakha 104 cultivar was broadcasted without nitrogen fertilizer application in both seasons. 


\section{Number of filled grains panicle ${ }^{-1}$}

Number of filled grains panicle ${ }^{-1}$ was significantly affected by methods of planting, rice cultivars and nitrogen fertilizer rates in 2014 and 2015 seasons (Table 2). Results show that plants under transplanting method produced the greatest number of filled grains panicle ${ }^{-1}$. Higher number of filled grains panicle ${ }^{-1}$ in transplanted rice may be due to availability of better light intensity, optimum spacing and efficient translocation of photosynthesis to the spikelets. Same result was found by Sekhar et al. (2014). Giza 179 rice cultivar produced more number of filled grains panicle ${ }^{-1}$ than Sakha 104. Increasing nitrogen rate up to $150 \mathrm{~kg} \mathrm{~N}^{-1}$ increased number of filled grains panicle ${ }^{-1}$ significantly. The promoting effects of nitrogen on number of filled grains panicle ${ }^{-1}$ were reported by Abd El-Hamed (2002).

Table 3: Panicle numbers $\mathrm{m}^{-2}$ and No. of filled grains panicle ${ }^{-1}$ as affected by interaction among methods, rice cultivars and nitrogen rates

\begin{tabular}{|c|c|c|c|c|c|c|}
\hline \multirow{2}{*}{ Method } & \multirow{2}{*}{ Cultivar } & \multirow{2}{*}{$\underset{\mathrm{ha}^{-1}}{\mathrm{Kg} \mathrm{N}}$} & \multicolumn{2}{|c|}{ No. of panicles $\mathrm{m}^{-2}$} & \multicolumn{2}{|c|}{$\begin{array}{l}\text { No. of filled grains } \\
\text { panicle }^{-1}\end{array}$} \\
\hline & & & 2014 & 2015 & 2014 & 2015 \\
\hline \multirow{8}{*}{ Broadcasting } & \multirow{4}{*}{ Giza 179} & 0 & 396.501 & 387.750 & $73.08 n$ & $72.90 \mathrm{k}$ \\
\hline & & 50 & $423.50 \mathrm{k}$ & $424.00 \mathrm{~m}$ & $85.25 \mathrm{I}$ & $84.77 i$ \\
\hline & & 100 & $483.25 i$ & 4 488.72j & $111.27 \mathrm{~h}$ & $107.80 f$ \\
\hline & & 150 & $509.00 \mathrm{~h}$ & $506.00 \mathrm{i}$ & $121.67 d$ & $120.25 c$ \\
\hline & \multirow{4}{*}{ Sakha 104} & 0 & $367.50 \mathrm{~m}$ & $371.25 p$ & 68.620 & $67.65 I$ \\
\hline & & 50 & 402.001 & $396.50 n$ & $81.10 \mathrm{~m}$ & $78.80 \mathrm{j}$ \\
\hline & & 100 & $429.25 \mathrm{k}$ & $432.00 \mathrm{I}$ & 93.95j & $92.62 \mathrm{~h}$ \\
\hline & & 150 & $455.25 j$ & $467.05 \mathrm{k}$ & $113.32 \mathrm{~g}$ & $111.72 \mathrm{e}$ \\
\hline \multirow{8}{*}{ Transplanting } & \multirow{4}{*}{ Giza 179} & 0 & $562.75 f$ & $574.06 f$ & $100.05 i$ & $98.37 \mathrm{~g}$ \\
\hline & & 50 & $592.25 d$ & $597.25 d$ & $117.45 \mathrm{e}$ & $115.22 d$ \\
\hline & & 100 & $618.50 \mathrm{~b}$ & $612.50 \mathrm{~b}$ & $123.50 \mathrm{c}$ & $122.55 b$ \\
\hline & & 150 & $658.75 a$ & 673.03a & $134.77 a$ & $133.32 a$ \\
\hline & \multirow{4}{*}{ Sakha 104} & 0 & $543.50 \mathrm{~g}$ & $546.57 \mathrm{~h}$ & $88.90 \mathrm{k}$ & $85.37 i$ \\
\hline & & 50 & $564.50 f$ & $566.03 \mathrm{~g}$ & $110.67 \mathrm{~h}$ & $109.32 f$ \\
\hline & & 100 & $584.00 \mathrm{e}$ & $583.54 \mathrm{e}$ & $115.52 f$ & $113.65 \mathrm{de}$ \\
\hline & & 150 & $604.50 c$ & $606.75 b$ & $127.27 b$ & $124.22 b$ \\
\hline
\end{tabular}

Means of each column designated by the same letter are not significantly different at $5 \%$ rate using Duncan's multiple range test.

The interaction effect among planting methods, rice cultivars and nitrogen fertilizer rates in both seasons on the number of filled grains panicle ${ }^{-1}$ (Table 3 ). Data show that there was a significant effect in number of filled grains panicle ${ }^{-1}$ due to the three-way interaction. Application of $150 \mathrm{~kg} \mathrm{~N}^{-1}$ to transplanted Giza 179 recorded the highest values of number of filled grains panicle ${ }^{-1}$. On the other hand, the lowest values were found when Sakha 104 was broadcasted without nitrogen fertilizer application. These results were true in both seasons. These findings are in close agreement with those reported by Sekhar et al. (2014).

\section{No. of unfilled spikelets panicle ${ }^{-1}$}

Number of unfilled spikelets panicle ${ }^{-1}$ was significantly affected by methods of planting, rice cultivars and nitrogen fertilizer rates (Table 
2). Plants under transplanting method recorded the greatest number of unfilled spikelets panicle ${ }^{-1}$. Same result was found by Laary et al. (2012). The highest number of unfilled spikelets panicle ${ }^{-1}$ was obtained by Sakha 104. Increasing nitrogen rate up to $150 \mathrm{~kg} \mathrm{~N} \mathrm{ha}^{-1}$ increased number of unfilled spikelets panicle ${ }^{-1}$ significantly. The clear effects of nitrogen on number of unfilled spikelets panicle ${ }^{-1}$ were reported by Bahmanyar et al. (2010).

\section{0-grain weight (g)}

Thousand -grain weight was significantly affected by methods of planting, rice cultivar and nitrogen fertilizer rate in 2014 and 2015 seasons (Table 4). The heaviest 1000 -grain weight was obtained by transplanting rice compared with direct seeding. This may be due to that plants gave better growth under transplanting due to regular spacing. Same finding was found by Ehsanullah et al. (2000). Sakha 104 rice cultivar recorded heaver 1000-grain weight than Giza 179. Nitrogen fertilizer application significantly decreased the 1000-grain weight. Thus, the highest values of 1000-grain weight appeared no nitrogen was applied. This is mainly due to the higher number of spikelets per panicle in plants received nitrogen at any rate than those did not which receive any nitrogen. So the sink capacity is high and the source is limited, therefore, the filling of grains was more and consequently the grain of weight was high. The promoting effects of nitrogen on 1000-grain weight were reported by Metwally et al. (2010).

Table 4: 1000-grain weight, grain yield and straw yield and harvest index of rice cultivars as affected by method of planting and nitrogen rates

\begin{tabular}{|c|c|c|c|c|c|c|}
\hline \multirow{2}{*}{ Factor } & \multicolumn{2}{|c|}{ 1000-grain weight (g) } & \multicolumn{2}{|c|}{ Grain yield $\mathrm{t}$ ha ${ }^{-1}$} & \multicolumn{2}{|c|}{ Straw yield $\mathrm{t} \mathrm{ha-1}$} \\
\hline & 2014 & 2015 & 2014 & 2015 & 2014 & 2015 \\
\hline $\begin{array}{l}\text { Methods M: } \\
\text { Broadcasting } \\
\text { Transplanting } \\
\text { F-test } \\
\end{array}$ & $\begin{array}{l}24.91 \\
26.39 \\
\star \star \\
\end{array}$ & $\begin{array}{c}27.09 \\
28.10 \\
\star \star\end{array}$ & $\begin{array}{l}7.69 \\
9.63 \\
\star \star \star\end{array}$ & $\begin{array}{l}7.62 \\
9.73 \\
\star \star\end{array}$ & $\begin{array}{c}9.31 \\
12.35 \\
\star \star\end{array}$ & $\begin{array}{c}9.21 \\
12.25 \\
\star \star \star\end{array}$ \\
\hline $\begin{array}{l}\text { Cultivars C: } \\
\text { Giza 179 } \\
\text { Sakha 104 } \\
\text { F-test }\end{array}$ & $\begin{array}{l}24.87 \\
26.43 \\
\star \star\end{array}$ & $\begin{array}{c}26.69 \\
28.48 \\
\star \star\end{array}$ & $\begin{array}{l}9.17 \\
8.14 \\
\star \star \star\end{array}$ & $\begin{array}{l}9.10 \\
8.25 \\
\star \star\end{array}$ & $\begin{array}{c}10.57 \\
11.10 \\
\star \star\end{array}$ & $\begin{array}{l}10.50 \\
10.98 \\
\star \star\end{array}$ \\
\hline $\begin{array}{c}\mathrm{Kg} \mathrm{N} \mathrm{ha}^{-1} \mathrm{~N}: \\
0 \\
50 \\
100 \\
150 \\
\text { F-test } \\
\end{array}$ & $\begin{array}{l}28.65 a \\
26.65 b \\
24.62 c \\
22.69 d \\
* \star\end{array}$ & $\begin{array}{l}28.95 \mathrm{a} \\
27.91 \mathrm{~b} \\
27.01 \mathrm{c} \\
26.47 \mathrm{~d} \\
\star \star \\
\end{array}$ & $\begin{array}{c}6.88 \mathrm{~d} \\
8.07 \mathrm{c} \\
9.48 \mathrm{~b} \\
10.19 \mathrm{a} \\
\star \star \\
\end{array}$ & $\begin{array}{c}6.92 \mathrm{~d} \\
8.01 \mathrm{c} \\
9.60 \mathrm{~b} \\
10.18 \mathrm{a} \\
\star \star *\end{array}$ & $\begin{array}{c}7.84 \mathrm{~d} \\
9.65 \mathrm{c} \\
12.14 \mathrm{~b} \\
13.72 \mathrm{a} \\
* \star\end{array}$ & $\begin{array}{c}7.83 \mathrm{~d} \\
9.59 \mathrm{c} \\
12.06 \mathrm{~b} \\
13.48 \mathrm{a} \\
\star \star\end{array}$ \\
\hline $\begin{array}{c}\text { Interaction } \\
\text { M X C } \\
M \times N \\
C \times N \\
M \times C \times N \\
\end{array}$ & $\begin{array}{c}* * \\
* \\
\text { N S } \\
\text { N S } \\
\end{array}$ & $\begin{array}{l}\text { N S } \\
* \\
* * \\
\text { N S } \\
\end{array}$ & $\begin{array}{l}* * \\
\star * \\
* * \\
* * \\
* * \\
\end{array}$ & $\begin{array}{l}\text { N S } \\
* * \\
* * \\
* * \\
\end{array}$ & $\begin{array}{l}* * \\
* * \\
* * \\
\text { N S } \\
\end{array}$ & $\begin{array}{l}* * \\
* * \\
* * \\
* * \\
\end{array}$ \\
\hline
\end{tabular}

${ }^{*},{ }^{* *}$ and NS indicate $\mathrm{p}<0.05, \mathrm{p}<0.01$ and not significant, respectively. Means of each factor designated by the same letter are not significantly different at $5 \%$ level using Duncan's multiple range test. 


\section{Grain yield $\mathbf{t} \mathbf{h a}^{-1}$}

Grain yield was significantly affected by the three studied factors in 2014 and 2015 seasons (Table 4). Transplanting methods produced more grain yield compared with direct seeded rice. This was mainly due to the transplanting technique gave maximum number of tillers, panicles per unit area, grains per panicle and 1000-grain weight than broadcast seeding technique. These findings are in close agreement with those reported by Javaid et al. (2012). Giza 179 rice cultivar gave the highest values of grain yield in both seasons. Such difference was mainly due to the genotypic variation. These results are in agreement with those obtained by Koutroubas and Ntanos (2003). Increasing nitrogen rate up to $150 \mathrm{~kg} \mathrm{~N} \mathrm{ha}^{-1}$ increased grain yield significantly. Increases in grain yield due to nitrogen application could be attributed mainly to the role of nitrogen in increasing most grain yield attributes (number of panicles $\mathrm{m}^{-2}$, panicle length, number of filled grains panicle ${ }^{-1}$ and panicle weight). Similar finding were reported by Gharib et al. (2011).

The interaction effect among planting methods, rice cultivars and nitrogen fertilizer rates in both seasons on the grain yield (Table 5). Data show that there was a significant effect in grain yield due to the three-way interaction. Application of $150 \mathrm{~kg} \mathrm{~N}^{-1}$ to transplanted Giza 179 cultivar recorded the highest values of grain yield. On the other hand, the lowest values were found when Sakha 104 cultivar was broadcasted without nitrogen fertilizer application. These results were true in both seasons. The differences in grain yield of Giza 179 rice cultivar between 100 and $150 \mathrm{~kg} \mathrm{~N} \mathrm{ha}^{-1}$ were not significant in both seasons under transplanting method. These findings are in close agreement with those reported by Chen et al. (2014).

Table 5: Grain yield and straw yield as affected by interaction among planting methods, rice cultivars and nitrogen rates

\begin{tabular}{|c|c|c|c|c|c|}
\hline \multirow{2}{*}{ Method } & \multirow{2}{*}{ Cultivar } & \multirow{2}{*}{$\mathrm{Kg} \mathrm{N} \mathrm{ha}^{-1}$} & \multicolumn{2}{|c|}{ Grain yield $t h^{-1}$} & \multirow{2}{*}{$\begin{array}{c}\begin{array}{c}\text { Straw yield } \\
\mathrm{t} \mathrm{ha}^{-1}\end{array} \\
2015 \\
\end{array}$} \\
\hline & & & 2014 & 2015 & \\
\hline \multirow{8}{*}{ Broadcasting } & \multirow{4}{*}{ Giza 179} & 0 & $6.38 \mathrm{j}$ & $6.40 \mathrm{j}$ & $6.87 \mathrm{I}$ \\
\hline & & 50 & $7.42 \mathrm{~h}$ & $7.11 \mathrm{~h}$ & $7.97 \mathrm{k}$ \\
\hline & & 100 & $9.19 \mathrm{e}$ & $9.24 \mathrm{~d}$ & $10.43 \mathrm{~g}$ \\
\hline & & 150 & $9.60 \mathrm{~cd}$ & $9.35 \mathrm{~d}$ & $11.33 \mathrm{e}$ \\
\hline & \multirow{4}{*}{ Sakha 104} & 0 & $6.10 \mathrm{k}$ & $6.03 \mathrm{k}$ & $6.97 \mathrm{I}$ \\
\hline & & 50 & $6.65 \mathrm{i}$ & $6.66 \mathrm{i}$ & $7.95 \mathrm{k}$ \\
\hline & & 100 & $7.30 \mathrm{~h}$ & $7.43 \mathrm{~g}$ & $9.69 \mathrm{~h}$ \\
\hline & & 150 & $8.88 \mathrm{f}$ & $8.75 \mathrm{e}$ & $12.49 \mathrm{c}$ \\
\hline \multirow{8}{*}{ Transplanting } & \multirow{4}{*}{ Giza 179} & 0 & $7.72 \mathrm{~g}$ & $7.70 \mathrm{f}$ & $8.47 \mathrm{j}$ \\
\hline & & 50 & $9.44 \mathrm{~d}$ & $9.38 \mathrm{~d}$ & $10.74 \mathrm{f}$ \\
\hline & & 100 & $11.75 \mathrm{a}$ & $11.74 a$ & $14.05 \mathrm{~b}$ \\
\hline & & 150 & $11.88 \mathrm{a}$ & $11.90 \mathrm{a}$ & $14.14 \mathrm{~b}$ \\
\hline & \multirow{4}{*}{ Sakha 104} & 0 & $7.33 \mathrm{~h}$ & $7.53 \mathrm{fg}$ & $9.00 \mathrm{i}$ \\
\hline & & 50 & $8.78 \mathrm{f}$ & $8.88 \mathrm{e}$ & $11.70 \mathrm{~d}$ \\
\hline & & 100 & $9.70 \mathrm{c}$ & $9.99 \mathrm{c}$ & $14.06 \mathrm{~b}$ \\
\hline & & 150 & $10.41 \mathrm{~b}$ & $10.74 \mathrm{~b}$ & $15.98 \mathrm{a}$ \\
\hline
\end{tabular}

Means of each column designated by the same letter are not significantly different at $5 \%$ level using Duncan's multiple range test. 


\section{Straw Yield $\mathrm{t} \mathrm{ha}^{-1}$}

The highest straw yield was recorded in transplanting method (Table 4) .The superior of transplanting may be due to better establishment and growth of rice plants than broadcast seeded method. Same result was found by San-oh et al. (2004). Sakha 104 rice cultivar produced more straw yield than Giza 179. The varietal differences in straw yield might be due to the differences in their genetic makeup. Increasing nitrogen rate up to $150 \mathrm{~kg} \mathrm{~N}^{-1}$ increased straw yield significantly. The increase in the straw yields might be mainly due to the fact that nitrogen application increased the accumulation of dry matter $\mathrm{g} \mathrm{m}^{-2}$, better growth of rice plant, internodes elongation and gibberellins activity. These findings are in close agreement with those reported by Singh et al. (2000).

Data in Table 5 show that there was a significant difference in straw yield due to the three-way interaction among planting of methods, rice cultivars and nitrogen fertilizer rates in the second season only. The highest values were recorded when transplanted Sakha 104 plants were fertilized with $150 \mathrm{~kg} \mathrm{~N} \mathrm{ha}^{-1}$. These findings are in close agreement with those reported by Sekhar et al. (2014).

\section{CONCLUSION}

It could be concluded that the Giza 179 show good performance for yield and yield characters under both two planting methods (Transplanting and Broadcasting). This due to the genetic background is different for tow cultivars. Also, the recommended from this study the Giza 179 is suitably cultivars under two methods and even with different rates from nitrogen fertilizer.

\section{REFERENCES}

Abd El-Hamed, M.I. 2002. Agricultural studies on rice. M.Sc.Thesis, Agron. Dept., Fac. of Agric., Kafr Elsheikh, Tanta Univ., Egypt.

Ali, Q. M., A. Ahmed ., M. Ahmed ., A . Ahmed ., M. A. Arain and M. Abbas. 2013. Evaluation of Planting Methods for Growth and Yield of Paddy (Oryza sativa L.) Under Agro-Ecological Conditions of District Shikarpur. American-Eurasian J. Agric. \& Environ. Sci., 13 (11): 1503-1508.

Anonymous. 2009. Food and agriculture organization of the United Nations. The state at food security in the world. p. 1-3.

Badawi, A. T. 1999. The final reported the national campaign of rice in Egypt. Ministry of Agriculture and the Academy of scientific Research and Technology, Cairo, Egypt (in Arabic).

Bahmanyar, M. A. and Mashaee, S. S. 2010. Influences of nitrogen and potassium top dressing on yield and yield components as well 
as their accumulation in rice (Oryza sativa). African Journal of Biotechnology. 9 (18): 2648-2653.

Chen, S., D. Wang., C. Xu., C. Ji., X. Zhang., X. Zhao., X. Zhang., B. Chauhan 2014. Responses of super rice (Oryza sativa L.) to different planting methods for grain yield and nitrogen-use efficiency in the single cropping season. Queensland Alliance for Agriculture and Food Innovation (QAAFI), University of Queensland, Toowoomba, Queensland, Australia. www.plosone.org.

Ehsanullah, I. Iqbal., A. Ahmad., and Randhawa, S. A. 2000. Effect of Direct Seeding and Transplanting Methods on the Yield and Quality of Fine Rice Basmati-370. International Journal of Agricultural \& Biology. 2 (3): 251-252.

F A O. 2004. The state of food and Agriculture 2003-2004. Agricultural Biotechnology meeting the needs of the poor. Food and agriculture organization of the United Nations.

Fageria, N. K. and Baligar, V.C. 2003. Methodology for evaluation of low land rice genotypes for nitrogen use efficiency. J. Plant Nutr. 26 (6):1315-1333.

Gharib, H. S., T. F. Metwally., S. S. Naeem and E. E. Gewaily. 2011. Influence of some stimulating compounds and nitrogen fertilizer levels on growth and yield of hybrid rice. Zagazig J. Agric. Res. 38 (1):1-21.

Javaid, T., I. U. Awan., M. S. Baloch., I. H. Shah., M. A. Nadim., E. A. Khan., A. A. Khakwani and Abuzar, M. R. 2012. Effect of planting methods on the growth and yield of coarse rice. J. Anim. Plant Sci. 22(2): 358-362.

Koutroubas, S. D. and Ntanos, D.A. 2003. Genotypic differences for grain yield and nitrogen utilization in Indica and Japonica rice under Mediterranean conditions. Field Crops Research. 83(3): 251-260.

Laary, J. K., W. Dogbe., P. O. Boamah and Agawini, J. 2012. Evaluation of planting methods for growth and yield of "Digang" rice (Oryza sativa L.) under upland condition of Bawku, upper east region, Ghana. arpn Journal of Agricultural and Biological Science. 7 (10): 814-819.

Metwally, T. F., E. E. Gewaliy., E. S. Naeem and M. M. El-Malky. 2011. Response of different promising rice genotypes to various nitrogen levels. J. plant production, Mansoura Univ. 2 (3):507520.

Metwally, T. F., S. E. M. Sedeek., A. F. Abdelkhalik and I. M. El-Rewiny. 2010. Varietal differences in physiological efficiency of nitrogen utilization in rice. Genetic Behaviour of Some Rice (Oryza sativa L.) Genotypes under Different Treatments of Nitrogen Levels American-Eurasian J. Agric. \& Environ. Sci. 8 (1): 27-34.

San-oh, Y., Y. Mano., T. Ookawa and Hirasawa, T. 2004. Comparison of dry matter production and associated characteristics between direct-sown and transplanted rice plants in a submerged paddy 
field and relationships to planting patterns. Field Crops Research. 87 (1): 43-58.

Sekhar, D., P. V. N. Prasad., K. R. Tejeswara and Venugopala, N. R. 2014. Productivity of rice as influenced by planting method and nitrogen source. Int.J.Curr.Microbiol.App.Sci. 3(8) 1063-1068

Singh, M. K., R. Thakur., U. N. Verma and R. R. Upasani. 2000. Effect of planting time and nitrogen on production potential of Basmati rice(Oryza Sativa, L.) cultivars in Bihar Plateay. Indian J. Agron., 45(2): 300-303.

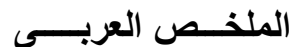

تأثير طرق الزراعة ومعدلات السماد النيتروجيني على إنتاجية الأرز

فؤاد عبد الحليم سرور * عادل يوسف رجب* تامر فاروق متولي ** أشرف عبد الفتاح

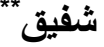

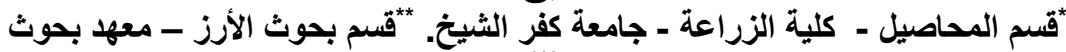

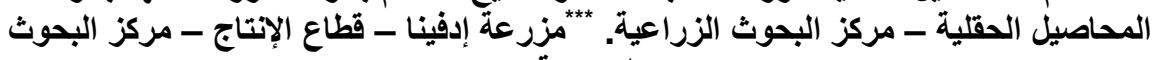
الزراعية . رئة

أقيمت تجربتان حقليتان لمحصول الأرز خلال الموسمين الزر اعيين 2014و 2015, وذلك إعلك

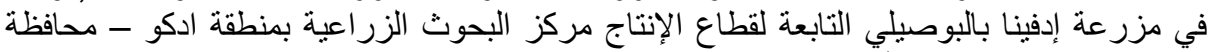

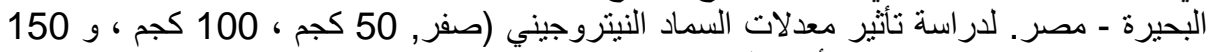

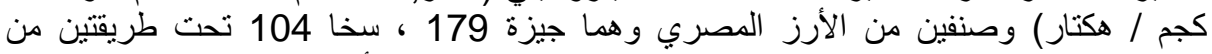

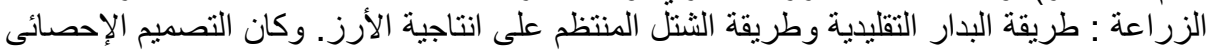

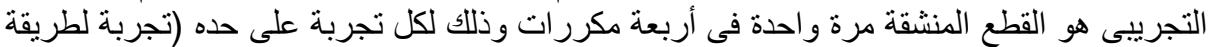

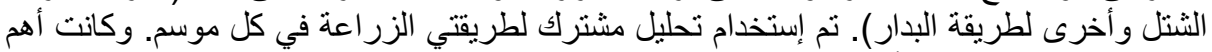

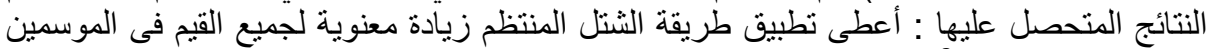

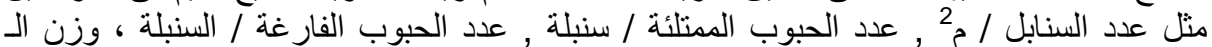
1000 حبة ، محصول الحبوب ومحصول القش بالمقارنة بطريقة البدار التقليدية خلال البلة الموسمين.

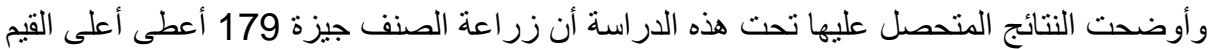

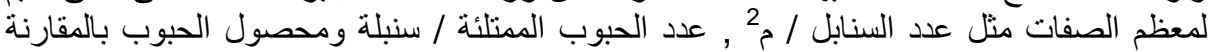

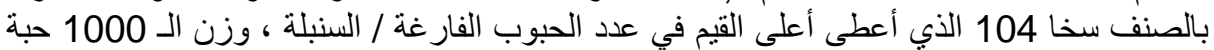

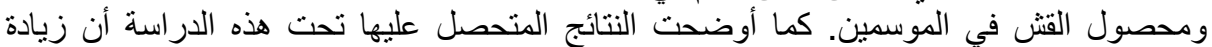

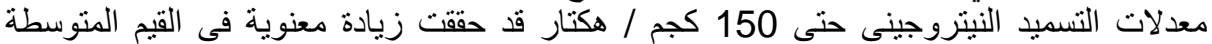

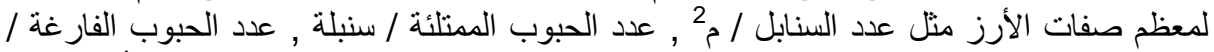

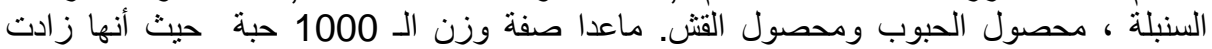

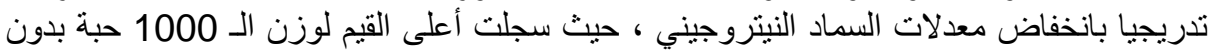

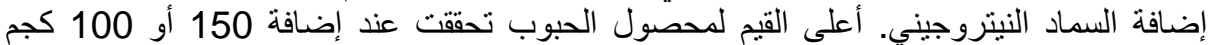

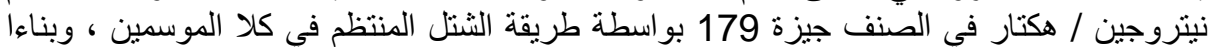

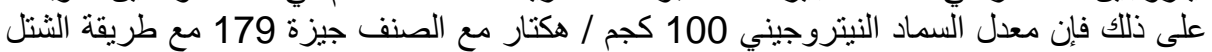

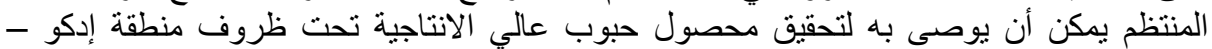

